\title{
The Making of Hybrid Stateness: Sources of Police Performance in the Conurbano*
}

La construcción de estatalidad híbrida: Fuentes del accionar policial en el conurbano

\author{
MATÍAS DEWEY \\ Max Planck Institute for the Study of Societies, Cologne, Germany
}

\begin{abstract}
By default, stateness is usually considered as a state's legal ability to deliver goods or services. This understanding implies that stateness is structured by the rule of law. However, as historical and current examples show, this legal ability often relies on practices that one would define as illegal and that any measure of 'stateness' must take into account. Using the case of the Police of the Province of Buenos Aires as an example, I propose the notion of hybrid stateness i.e. an understanding of stateness that considers the state's ability to operate illegally. This short piece addresses the institutional and budgetary setting of the provincial police force and tackles the question of where the illegal resources for performing police's duties come from.
\end{abstract}

Key words: Hybrid Stateness, Illegality, Police, Buenos Aires, Protection.

\begin{abstract}
RESUMEN
Por omisión suele considerarse a la estatalidad como la capacidad legal del Estado para suministrar bienes y servicios. Esta forma de entender la estatalidad supone que ella está estructurada por el derecho sancionado. Sin embargo, ejemplos pasados y presentes muestran que dicha capacidad legal suele apoyarse en prácticas que bien pueden definirse como ilegales y que cualquier medición de 'estatalidad' debería tomar en cuenta. Tomando como ejemplo el caso de la Policía de la Provincia de Buenos Aires propondré la noción de estatalidad híbrida, esto es, una comprensión de la estatalidad que considera la capacidad del Estado para operar ilegalmente. Este breve artículo aborda los condicionamientos institucionales y presupuestarios así como la cuestión sobre el origen de los recursos ilegales en los que se basa la actuación policial.
\end{abstract}

Palabras clave: Estatalidad híbrida, ilegalidad, policía, Buenos Aires, protección.

* This article is part of the Millenium Nucleus for the Study of Stateness and Democracy in Latin America, Project NS100014, of the Ministry of Economy and Tourism of Chile. 


\section{INTRODUCTION}

Although always present in everyday life, the problem of illegality is underrepresented in the social sciences. This is especially true when focusing on basic questions such as 'how social order is achieved' or 'which the instances that produce such order are'. 'Order' is commonly associated with the division between 'state' and 'society'. Accordingly, two sources of order are identified. First, the state, through its monopoly over the means of violence and other state institutions; second, inner society, in the form of social capital and networks. ${ }^{1}$ We omit organized criminal groups, who are on the flipside of civil society as a possible source of order in this picture. Quite the opposite: individuals or groups who disregard state regulations are portrayed as producers of disorder and disruption. However, problems for the social sciences arise once we see grey areas that challenge common assumptions. For instance, when states act illegally in order to respond to social demands, or when criminal groups deliver public services.

Having the question about the extent to which states are able to produce order in society as backdrop, another problem relates to its capacity. Studies on this matter assert that the state needs a certain degree of autonomy in order to be capable of controlling behaviour or providing services to citizens. Autonomy and capacity, in this view, only exist as features of the state when individuals who occupy positions of power within the state structure behave according to the rule of law. In this sense, stateness is understood to be structured by the rule of law. ${ }^{2}$ One may hardly assert that phenomena related to the 'unrule of law' have not been taken into account by representatives of this approach. These accounts have, however, focused almost exclusively on the disrupting effects of acting beyond the law and not on the capacity for producing order. ${ }^{3}$ A direct corollary of identifying informal or illegal behaviour with disorder is a one-sided view, in which order is only achieved by legal means.

In this short piece, I will argue that a part of the state in the province of Buenos Aires engages, and indeed relies on, illegal activities and that any measure of 'stateness' must take this into account. My argument will contend that informal politics and the enforcement's capacity of non-state armed actors play a most important role. This contribution will thus propose that our understanding of stateness should not be restricted to the state's legal ability to deliver goods or services, but also to its ability to operate illegally or beyond the law. In other words, it will be possible to conceive a hybrid form of stateness largely present in studies on state-building processes. From this perspective, neither state strength nor state capacity are necessarily understood as pure legal features. I am aware that this view contends assumptions by which a state cannot be strengthened through

1 This classical view of society has a good example in Max Weber's work 'State and Society'. A different view is, for instance, the theory of systems in which the political system represents the state and society is grasped as divided in subsystems.

2 I refer here to the discussions on stateness during the Stateness Conference. Nevertheless, it is a common assumption that the capacity dimension of stateness is structured or governed by the rule of law. For a recent example see Matthews (2012).

3 Méndez (1999). 
illegal activities i.e. state strength ensues only from the law-abiding behaviour of state servants. The underlying assumption in this view is that a strong state is per se a legal state. However, as history shows, this strength often relied on practices that one would nowadays define as illegal. In fact, from this perspective, at least until the consolidation of the European states during the $19^{\text {th }}$ century, the various states' capacity and autonomy depended strongly on practices such as piracy, privateering and mercenarism promoted by the states themselves. Thus, states were able to produce order by delivering services due to their ties to what Janice Thomson called 'organized terrorism' ${ }^{4}$ Though historical cases differ in some respects from contemporary states, it is important to recognize the extent to which pernicious and violent activities, widely practiced by European states and nowadays delegitimized, strengthened states and increased their autonomy. By referring to European history I do not attempt to argue that strong states have currently achieved this quality precisely because prior illegal activities strengthened their structures. Such a teleological assumption would imply that the Argentinean state is going through an early stage of evolution and that becoming a strong state is just a matter of time. Far from this, my purpose is quite modest. The reference to past examples aims only at showing that features attributed to a strong state, such as its capacity to collect taxes or to impose order were not always the result of law-abiding behaviour. A more concrete example is Clark's account of the formation of the early Prussian state. He asserts that "there was [first] the regular 'contribution', a combined land and poll tax levied by the Brandenburg government upon its own population to support the Elector's army. Then there were the numerous legal and illegal levies raised by foreign and home troops". ${ }^{5}$ Thereby, the purpose of this paper is to attract the attention to the fact that attributes of the state such as "strength" or "ability" do not necessarily imply pure acts of legality.

As the following case study will demonstrate, by excluding illegal practices carried out by the state one gets a severely distorted picture of the state's capacity. The case of the police of the province of Buenos Aires suggests that the most commonly used descriptions such as 'corruption', even when corrupt practices facilitate the integration of state hierarchies, do not capture the very simple fact that this police organization partially finances its everyday duties at the police stations by selling protection to criminals. ${ }^{6}$ In other words, the supply of services to citizens as well as the police's operational capacity is intimately related to illegal actions.

This short article proceeds as follows. First, I conceptually frame the idea that stateness, understood as a stock of resources, might be illegally generated by both state and nonstate actors. ${ }^{7}$ This understanding of stateness emerges in a broader context of studies about new forms of sovereignty and governance. Second, I illustrate the problem of hybrid stateness with the case of the Police of the Province of Buenos Aires and its

\footnotetext{
Thomson (1994).

Clark (2007), p. 31.

To the reinforcing effect of corruption over hierarchy see: Darden (2008).

I refer here to the definition of stateness provided by Daniel Brinks and Sebastian Mazzuca during the Stateness Conference.
} 
budgetary and institutional setting. ${ }^{8}$ Third, I briefly tackle the question of the police's ability to perform its duties. I have developed this elsewhere with an emphasis on informality. ${ }^{9}$ Finally, I summarize the findings and pose some questions for the analysis of state capacity in Latin America.

\section{THE HYBRID STATENESS}

In recent years, there has been an increased interest among specialists in new forms of governance provided by non-state armed actors. In a broad sense, research in this field refers to governance as rules and norms that regulate the exchange of certain goods or services. ${ }^{10}$ According to this view, in a given social context, criminal groups are able to control the exchange of, for instance, drugs, humans, vehicles, organs or endangered species. Even when these groups are highly skilled in delivering goods or services, this type of governance alludes predominantly to an economic regulation. A similar orientation characterizes a special subtype of organized crime, namely mafia groups which do not attempt to control one but any type of transaction by selling an abstract commodity: protection. Mafia groups in Sicily, ${ }_{1}^{11}$ Russia $^{12}$ or Japan ${ }^{13}$ thus actively facilitate economic transactions through the supply of trust. Nevertheless, underlying these analyses remains a strict distinction between two different spheres. On the one side, the state's behaviour attached to legal norms and on the other side, criminal groups' behaviour oriented towards illegal business. Hence, the relationships between both spheres, which are far from being only confrontation and conflict, are commonly described as corrupt ties or clandestine connections. ${ }^{14}$ Less attention, however, has been paid to forms of governance and sovereignty which comprise a sort of 'dirty togetherness' of outlaws with state actors. The number of studies of this perspective has increased in the last years. ${ }^{15}$ If the aforementioned studies assume the presence of two dissimilar forms of logic -state and criminals- bridged only by means of corruption, the form of governance I am pointing to derives from a virtual fusion of state and non-state oriented interests. Unlike

The data presented here is part of a more extensive study centered on 'protection selling' carried out by the police of Buenos Aires and the market for stolen cars. This study is based on 21 in-depth interviews. Only a few interviews could be recorded. In the majority of cases, the interviewee did not give his/her consent, and in some cases the conditions of the dialogue did not allow it. I relied also on two sources of documentary evidence. First, I had access to a considerable variety of Investigaciones Sumariales Administrativas (Summary Administrative Investigations), Investigaciones Penales Preparatorias (Preparatory Penal Investigations) and memoranda, all pertaining to two tenures of office of the Ministry of Security for the province of Buenos Aires. Second, I had access to documentation of the legal proceedings against those responsible for leading "chop shop" rings provided by the Dirección Nacional de Fiscalización de Desarmaderos y Autopartes (National Direction of Control of Auto Dismantlers and Auto Parts, DNFDA).

Dewey (forthcoming).

Varese (2010), p. 13.

Blok (1975); Gambetta (1993).

Volkov (2002); Varese (2004).

Kong Chu (2000).

Della Porta and Vannucci (1999); McC Heyman (1999); Green and Ward (2004).

Davis (2010); Reno (1995); Desmond Arias (2006); Clunan and Trinkunas (2010); Kupatadze (2012); Dewey (2011). 
criminal groups or the mafia whose actions are not primarily politically oriented, this particular constellation articulates different interests, economically but also politically motivated. Accordingly, this fusion of logic results in a type of governance based on a matrix of both legal and illegal businesses, which reinforces the asset-grabbing mode of corrupt bureaucracy. ${ }^{16}$ However, the most important feature of this governance is its capacity to satisfy rising demands for services among the population and to increase state capacity to bring social order by -illegally- disciplining social sectors. Such nonprescriptive perspective of governance and state capacity challenges common assumptions, especially those whose starting point is the distinction between strong and weak states.

In fact, these social spaces are the result of actions regulated or negotiated between state and non-state actors. The current expansion and growth of illegal activities in Latin America is not merely the result of the most powerful criminal organizations, but also the result of state agencies that regulate, negotiate or tolerate illegal activities because of the availability of economic resources or the achievement of social order. ${ }^{17}$ Hence, the argument put forward here is that state agencies actively influence the generated order, whether to a greater or lesser degree. Accordingly, this order is achieved either through regulation, because state organizations themselves have control over illegal means, or through a certain degree of tolerance, because organized crime groups provide suitable output (basic services, maintenance of order, territorial occupation, etc.).

The particularity of these state-non-state armed actors ties is that the relationship transcends corruption and has an infrastructural impact. It arises from opportunities for resource extraction, which in time become markets that should be ensured and maintained. ${ }^{18}$ These "cooperative" ties are, however, the result of specific historical trajectories in which violence plays a prominent role. Indeed, in the course of these trajectories, the state's and other groups' capacities for monitoring this relationship and enforcing rules are put into play. From the point of view of the state, alliances with criminal groups can become a way of extending political and economic influence over territories and populations or of "outsourcing" to third parties to perform tasks that cannot be disclosed. ${ }^{19}$ From the perspective of criminal groups, alliances with the state are a way to secure markets, improve business and to obtain any advantage over competing groups. ${ }^{20}$ From a historical perspective, this relationship between the state and organized crime has different patterns. Whereas the process of European state centralization is the result of an extraction-coercion circle and constant war between states, the state-building in the Ottoman Empire and in the republics of the former Soviet Union is the result of a constant negotiation, co-optation and conflict with bandits. ${ }^{21}$ In Latin America, meanwhile, the absence of external threats resulted in a less

\footnotetext{
$16 \quad$ See Kupatadze (2012), p. 187.

17 On the idea of state's regulation of illegal activities see Reuter (1984); Haller (1990); Saín (2008). On economic order beyond the law see: Neuwirth (2011).

Wilson (2009); Ruggiero (2001); Ruggiero (2009).

Kupatadze (2012).

Davis (2010).

Tilly (1985); Barkey (1994); Kupatadze (2012).
} 
developed state's infrastructure and, therefore, in a weak capacity to penetrate society. ${ }^{22}$ Nevertheless, it should be noted that regardless of the pattern adopted, criminal groups tend to develop legal businesses whose success depends on the ongoing functioning of illegal business. ${ }^{23}$ In short, the importance of this lies in the legal-illegal network that is geared both to the supply of goods and services and to the construction of a relatively predictable social order. ${ }^{24}$

In the case of the police of the Province of Buenos Aires, the illegal extraction of resources by the police through the sale of protection to criminals should be understood in terms of an "informal taxation". ${ }^{25}$ Moreover, this comprises an asymmetrical relationship in the sense that the police hold relative control over criminal groups. Closely observed, informal taxation refers to two elements related to the state's capacity to provide services: i) the organized way of the extraction of resources, and ii) the infrastructural impact of such extraction. In other words, informal taxation is far from being a sporadic and individual action connected to personal enrichment, but rather an informal institution that allows the financing of politics or the improvement of the state's extractive capacity. It is worth mentioning that, as the case of the police of the province of Buenos Aires shows, the extraction of resources is based on the exploitation of illegal markets, which is also accepted or tolerated by -at least- a portion of the population. ${ }^{26}$ These are the markets for stolen car and auto parts, for drugs and for humans.

As discussed below, the institutionalization of certain unlawful practices linked to illegal markets is not possible without tolerance, even a certain amount of activism practiced by local political leaders. Thus, as Davis pointed out, informal politics among political parties, NGOs, private companies and criminal organizations, plays an essential role as a regulatory mechanism of violence and conflict. ${ }^{27}$

\section{HYBRID POLICE STATENESS IN THE PROVINCE OF BUENOS AIRES}

Moving from the general remarks, I will present the setting in which this sort of hybrid stateness takes place. I will therefore show how illegal practices are also part of the stock of resources used to provide security to the population. The point of departure should be the fact that the police are able to operate and carry out basic duties, which in general terms means capacity to react to individuals' demands and to monopolize the means of violence. In other words, the police have a dominant position over criminal groups. This fact is also important in order to understand patterns of state-criminal relations in the Southern Cone. ${ }^{28}$ Such police capacity should not be understood as the mere end

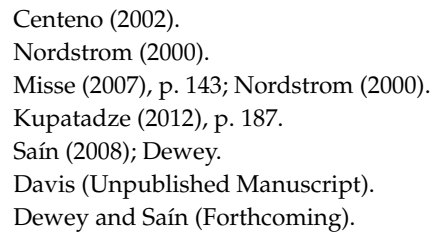


result of illegal practices, but as a combination of both legal and illegal ways of capturing resources. It is in this context, that the expression 'hybrid stateness' starts to make sense.

\section{Budgetary and Institutional Setting}

Routinized illegal practices carried out by police personnel in Buenos Aires are motivated by two concerns: On the one hand, as many authors have demonstrated, stateness is a product of history in European countries. ${ }^{29}$ The logic of police operations in Argentina is not novel in this sense, as its origin dates back to the end of nineteenth century. ${ }^{30} \mathrm{On}$ the other hand, there are institutional dynamics that encourage active interventions in the underground. As we will see, informal taxes collected by the police primarily benefit local leaders who need to finance an expensive political career, but also they are useful for dealing with huge budgetary problems.

Ever since their formation as state organizations, the provincial police forces, including the Buenos Aires police, have been closely connected with political parties, at the local or provincial level. ${ }^{31}$ For this reason, following Marcelo Saín, it proves useful to define the relationship between politicians and the police force as a reciprocity pact that continues to the present day. According to the limited academic literature on the police force in the province of Buenos Aires which mainly deals with police reform in the framework of democratization, this link is maintained by a kind of "double activism". On the political side, there is a sort of non-official interference with the police institution and a selective protection of certain police officers which is manifested in promotions and the appointment of postings. On the police side, an acceptable formal or informal control of criminality, as well as the provision of certain 'services' during election periods are guaranteed. Here, 'acceptable crime control' means the absence of protests or social claims which results in the loss of political capital. The direct consequence of this reciprocity pact, even during the democratic period, would be a progressive autonomy, both functional and programmatic, of the police organization; or that the police force of the province of Buenos Aires does not operate independently from political parties. On the contrary, it organizes itself by auto-regulating the instances of contact with the latter.

A report on the results of the tenure of former Minister of Justice and Security of Buenos Aires, Carlos Arslanián, states that the budget of the initial phase of his second period in power (2004-2007) was in deficit. This report implied a lack of information systems, insufficient material resources, absence of purchases -for equipment, clothing, communications and computing purposes and other such shortfalls- a lack of both a purchase policy and an infrastructure plan, a deficient sanitary service, etc. This set of problems is apparently not new to the police force. More than 100 years ago, other authors highlighted the existence of similar difficulties. ${ }^{32}$ Moreover, Marcelo Saín states that "the huge amount and diversity of administrative and operative activities presently

Reinhard (2007).

For one example to the Federal Police see Kalmanowiecki (2003).

Gayol (1996); Kalmanowiecki (2003); Barreneche (2010); Johnson (1990); Zimmermann (1998).

Saín (2008). 
carried out by the police requires a prominent infrastructural and functional display that is often not financed with funds from the state budget formally allocated to the institution". Does this mean that police intervention in illegal markets such as the drug or stolen cars market is an answer to the lack of infrastructure and necessary resources? In what follows, I will address this question by referring to double conditioning. On the one hand, the police force faces shortfalls that undoubtedly act as a cause of the sale of illegal practices. On the other hand, however, there is a political activism, carried out mainly by mayors, that seeks to maintain the status quo. By promoting illegal police behaviour at the local level, which is, in turn, paid off with enrichment possibilities, mayors and brokers attempt to ensure both financial and power resources: the first for financing political campaigns, and the second for keeping social order. In the course of an interview, Supervision Officer Carlos referred to the financing subject:

"You see, we are in April [2010] and all the police stations of the province have been waiting since last October for the petty cash money to arrive. I say this so you have an idea of the financing question. I don't want to justify the things that are done, but this is to have a more global view. Look, a police officer, a low-ranking one, is currently working 8 normal hours. Four CORES, 6 additional hours, if they are paid, and that gives you a total of 3,600 pesos. And you are out of your house all day for that dough, which today is not enough for anything". ${ }^{33}$

While Carlos mentioned a debt that jeopardizes the minimum operation of a police station, Marcelo Saín proposed an exercise that clearly demonstrates the problem:

"There is a huge budgetary deficit. The police force of Buenos Aires has 55,000 men, and when people want more security they ask for more policemen. [...] If one day the police force stopped illicitly collecting money, [that is to say if] they didn't get anything from anywhere or anyone, then [the force] may be able to operate for only the first ten days of a month". ${ }^{4}$

If the first condition arises out of these budgetary and structural deficits, the federal institutional design is the second factor. ${ }^{35}$ It acts as a corset that delimits the transactions between the police force and politics and promotes the sale of protection. In this federal scheme, the power held by mayors at the municipal level is used to exert influence on the decisions adopted in terms of policing at the provincial level. According to interviewees, the police situation in the province of Buenos Aires cannot be explained without alluding to the figure of the mayor and the role that he plays in the appointment and maintenance of chief officers. This anecdote exemplifies their power:

"There is a recent case that occurred less than a month ago. So, the [security] minister [of the province of Buenos Aires] gets mad at the chief of San Eusebio's departmental. Then he calls Sánchez [the police chief] and tells him: 'Sack him! I don't want him overtime.

$34 \quad$ Marcelo Sain, Interview, 12.12. 2011.

35 On the interplay between federalism and police reform see: Eaton (2008). 
here anymore!' The guy [the departmental chief] had 33 years of service. And so Sánchez tells him, 'Why don't we wait, make all of them redundant and include him as well.' [The Minister replies,] 'No, no! Now, now!' Sánchez says, 'OK.' Then the police chief calls the precinct chief and tells him 'Remove San Eusebio's departmental chief and put the second one in charge.' That happened on a Thursday afternoon. So they go, remove him and put the second one in charge. It turns out that the [relieved] departmental chief calls Mr. Cardinal [San Eusebio's mayor] and tells him 'Listen, I was given the sack.' 'Don't worry,' [replies the mayor]. Mr. Cardinal calls Mr. Alonso [the governor] and tells him that he wants the departmental chief back. Governor Alonso calls the security minister and on Monday the departmental chief is back at his post. See how far the mayor's power extends?"

We can observe a common mechanism with this example, whose centre of gravity is the mayor's electoral power. The departmental chief has the chance to put pressure on the provincial authorities indirectly. In this way, not only does he keep his job, but he also has the chance to take part in the commercial opportunities that the area of San Eusebio offers him. On the other hand, the actions taken by Mr. Cardinal are explained by his own need, as is well put by Eaton, "to derive substantial funds from the illicit conduct of police officers, funds that are useful in hard-fought and increasingly expensive political campaigns". ${ }^{36}$ In this sense:

"During campaign times there is an increase in crime because the police let the rackets do their work. Letting their businesses run is a means for politicians to raise money during campaign times. That is the reason why at that time there is also a decrease in drug seizures; there is a need to sell. The deal for the mayor is to win money that is then passed on to the chief officer. And it is also meant for other things. For instance, to leave the "punteros" [neighbourhood brokers] free to commit armed robberies. The "punteros" work for the mayor during the day and at night they commit armed robberies". ${ }^{37}$

The evidence suggests that this political-police joint venture is based on the constant extraction of resources generated by the sale of protection, which is used to cover different financing needs: political campaigns, the lack of resources at the police institution, and the illicit enrichment of police chiefs and politicians. ${ }^{38}$

\section{GENERATING A STOCK OF RESOURCES}

Where do the illegal police resources come from? After briefly presenting the budgetary and institutional conditions in which this kind of stateness arises, I will show the three specific forms of collecting both financial and informational resources. These three types of mechanisms for extracting resources by means of selling illegal protection to 
criminals were presented elsewhere. ${ }^{39}$ It could be understood as a 'commodification' of the policemen's position of power, aimed at gaining the aforementioned resources. However, the ways policemen sell such 'suspension of enforcement' in order to get resources take on different forms. In the following, I will examine three forms of protection using the market for stolen vehicles in Buenos Aires as a reference point. The generation of resources is carried out in three specific ways. The common denominator of all of these is administrative tampering.

First, arresting people for legal or illegal reasons to collect a sum of money for the release of the prisoner is the most common form of gathering money. People who committed crimes -for example, criminals with arrest warrants ${ }^{40}$ - as well as others who did not -in general, known criminals- are arrested to charge them for their release, either for cash or for part of the loot. ${ }^{41}$ In some cases, this form is related to the recruitment of teenagers and the supply of police protection so that they can commit crimes. But the logic of arrest-release, as well as the recruitment reaches their limit with the emergence of conflicts. Indeed, the deaths of young men in alleged confrontations with the police seem to be a consequence of the breach of the informal contractual relationships between the police and their clients. ${ }^{42}$

Second, the release of areas (liberación de zonas) from the interference of the rule of law is an effective mechanism for the sale of protection that stimulates the operation of the three main criminal markets in Buenos Aires. In these cases, protection is delivered in order to cover fixed targets, such as "kitchens" or places to store cocaine, chop shops and so forth, or moving targets such as people or vehicles. ${ }^{43}$ In any of the cases, those policemen who offer protection require an exhaustive knowledge of the territory as well as a certain degree of logistics coordination. Supervision Officer Carlos expressed that "the person who gives the order to release an area at a specific time and street is the officer on duty or the chief officer".

Third, the protection for informants is another form of collecting resources, in this case information. At the same time, this form is used to gain interests -economic or of prestige- as well as to regulate the markets. In an insecure world such as the criminal one, quality information is a precious commodity. There are thus enough reasons for criminals to trade information in exchange for protection and/or money. Meanwhile, the police have the possibility of benefiting economically or of gaining prestige if they

39 Dewey (Forthcoming).

40 Interview with Houdini, former general auditor of the Internal Affairs Bureau of the province's police force.

41 Interview with Carlos, León C. Arslanián, former minister of the Ministry of Security of the province of Buenos Aires, and Eugenio Zaffaroni, minister of the Supreme Court of Justice of the Nation.

42 The proliferation of dead young men in the Lomas de Zamora district during the crisis of 2001 originated judicial inspections that are recorded in a report of the Human Rights Department of the Government of Buenos Aires. Another example is the Administrative Summary Investigation No. 4389/302 file No. 21.100-638285/01 that investigates the death of a sixteen-year-old boy in an alleged confrontation with two policemen. Other forms of conflictive situations, for example with the so-called piratas del asfalto are "solved" through similar methods. Interview with Arslanián.

43 Interview with Roberto Vásquez, former Undersecretary of Investigations and Criminal Intelligence. Since each type of crime implies a specific coordination, there are several kinds of land liberation. 
manage to intercept valuable information. An interviewee, for instance, suggests that there are chief officers who buy information related to drug cargos -coming from other provinces or bordering countries- and with this they organize drug seizures that, due to widespread media interest, earn them promotions or awards. ${ }^{44}$

These three forms of gathering resources could not be rightly understood without mentioning the administrative-bureaucratic mechanisms that allow for their invisibility. The "arrest-release" of people, releasing areas, and informant protection all require constant tampering with records or submitting certificates intended to conceal multiple irregularities that occurred during the protection sale. Consequently, the broadly considered legal system is an essential component when absorbing the demands of illegality and maintaining a legal appearance of police actions. This stage, however, is not reached with police participation alone. In many of the documents, it can be verified that the acquisition of certificates, authorizations or permits is common place, without which illegal businesses could not have prospered. Investigations stemming from the murder of María Victoria Chiaradía and Héctor Iglesia Braun suggest the collaboration -or omission- of different instances of the judicial system, or at least omission. ${ }^{45}$ Other memoranda indicate that the contact with the legal system does not necessarily mean the collaboration of public officers. An example of this is the purchase of wrecked cars with car ownership papers in public auctions. First, the buyers of the wrecked vehicle will sell it again as scrap and then they will start to search for -and steal-a vehicle with the same characteristics as the one that will be cloned with the papers of the purchased car. Finally, they will have a "new" vehicle that may be sold as a remis (fixed-fare taxi) in Greater Buenos Aires or as spare parts. ${ }^{46}$ In spite of the judicial participation in the promotion of this business, police are clearly active in tampering with documents. ${ }^{47}$ There, besides registering complaints of theft by policemen during the events of December 2001 and cover-ups of brothels, the chief officer and street service of Lanús are accused of protecting chop shops. It can clearly be seen in these documents that the protection becomes an administrative cover-up -that is to say, drawing up documents that state that, after police inspection, there is "nothing unusual to report". ${ }^{48}$

Interview with Carlos. This type of operation results in the driver of the transport being arrested (and maybe his companion as well).

45 Criminal proceedings determined that María V. Chiaradía and Héctor Iglesia Braun were killed when they traveled in a car with identical characteristics to what a criminal organization was looking for. This organization, specialized in 'cloning' cars, already owned a wrecked car Corsa and was looking to steal a functioning Corsa in order to clone it. Preliminary Criminal Investigation 22.318, María Victoria Chiaradía and Héctor Iglesia Braun, victims of aggravated murder. Ministry of Security of Buenos Aires. Judgement, April 2003.

46 Memorandum, Subject: "Desarmaderos, Dirección de Prevención de Delitos contra la Propiedad del Automotor", Buenos Aires, 2002. This was confirmed in the interviews with Fernando Antar and Juan Pablo Moyano, official of the National Direction of Control of Auto Dismantlers and Auto Parts of the National Ministry of Justice.

47 This can be verified by the Administrative Summary Investigation 4679/702 of 2002.

48 Tampering with public documents is a common practice confirmed by the two former auditors of Internal Affairs who were interviewed. For example: Administrative Summary Investigation 4679/702, General Audit of Internal Affairs, Ministry of Security of Buenos Aires, 2002. Refer to appendix; Memorandum, 9 August 2002, about the criminal complaint against a Deputy Chief Officer and a Deputy Inspector for tampering with the logbook. 


\section{CONCLUSIONS}

In this short piece, I argued that our understanding of stateness should not be restricted to the legal capacity of the state to deliver services to citizens. On the contrary, a broader perspective captures an additional and very common phenomenon: the ability of state actors to act illegally when they are pursuing their duties. This apparent contradiction refers less to supposedly irreconcilable logic and more to a confluence of interests, one which comprises state and non-state actors. In the province of Buenos Aires, this convergence might be observed in the way the police create their own secondary pool of resources, one that functions historically as a complement to the official budgetary allocation. The police regulation of illegal markets, whether stolen cars, drugs or women for prostitution, thereby performs a sort of 'behind the scenes' of the police's everyday capacity for carrying out their duties. Budgetary but also political and institutional constraints set a dynamic in motion, in which several actors take advantage and continuously reinforce behavioural patterns. On the basis of a chronic budgetary deficit, the police force seeks to maintain a certain degree of operational autonomy that an alternative financing source makes possible. However, this informal taxation of illegal markets is only possible due to the tolerance or direct implication of local politics in illegal businesses. This is the sense in which the above mentioned 'political activism' on behalf of police officers appointed at a local level should be understood i.e. the political interest in police chiefs who may eventually render special services during political campaigns or security crises. I also provided empirical evidence that shows three different forms of selling protection in the 'commodification' of the monopoly of violence, which in the end are three forms of producing state capacity. Through the "arrest-release" of people, releasing areas, and informant protection, the police gather resources used for personal enrichment but also, and this is the very important point, for purchasing spare parts and petrol for patrol cars, ink for printers, paper, uniforms, paint for the building as well as for setting up informal systems of additional retirement money, or just simply for supplementing low salaries. Due to budget shortfalls and to these illegal actions, the police force is able, for example, to receive crime reports from citizens, to spy on traffickers or to patrol neighbourhoods.

This understanding of stateness and state capacity also suggests a line of enquiry for further research. What from a prescriptive point of view might be described as reprehensible lack of state capacity, could be characterized from a more neutral or 'close-to-the-facts' perspective as hybrid type of stateness. Thus, a set of fascinating questions emerges: Why, despite the fact that no official legislation or policy directs the police to engage in illegal activities, are these so prevalent and deeply rooted? How should we revise our concept and measurement of "stateness" if we take the state's involvement in illegal activities seriously? What analytical tools might give us a better understanding of the mechanisms which reproduce the relationships the paper points to? Located at the interface between political science and historical and fiscal sociology, these questions pose problems that require moving away from a normative conceptual approach, to another that incorporates an understanding of the state in which illegality is taken seriously. 


\section{REFERENCES}

Barkey, Karen. 1994. Bandits and Bureaucrats: The Ottoman Route to State Centralization. Ithaca; London: Cornell University Press.

Barreneche, Osvaldo. 2010. “La Reorganización de las policías en las provincias de Buenos Aires y Córdoba, 1936-1940". In: http:/ / historiapolitica.com/biblioteca (31 August)

Blok, Anton. 1975. The Mafia of a Sicilian Village, 1860-1960: a Study of Violent Peasant Enterpreneurs. New York: Harper \& Row.

Centeno, Miguel Angel. 2002. Blood and Debt: War and the Nation-State in Latin America. University Park: Pennsylvania State University Press.

Clark, Christopher. 2007. Iron Kingdom: The Rise and Downfall of Prussia, 1600-1947. London: Penguin.

Clunan, Anne L. and Harold A. Trinkunas. 2010. Ungoverned Spaces: Alternatives to State Authority in an Era of Softened Sovereignty. Stanford: Stanford Security Studies.

Darden, Keith. 2008. "The Integrity of Corrupt States: Graft as an Informal State Institution". Politics \& Society 36: 35-59.

Davis, Diane E. 2010. "Irregular Armed Forces, Shifting Patterns of Commitment, and Fragmented Sovereignty in the Developing World". Theory and Society 39: 397-413.

Davis, Diane E. "Analytical Foundations for the Study of Informality: A Short Introduction". Unpublished Manuscript.

Della Porta, Donatella and Alberto Vannucci. 1999. Corrupt Exchanges: Actors, Resources, and Mechanisms of Political Corruption. New York: Aldine de Gruyter.

Desmond Arias, Enrique. 2006. Drugs and Democracy in Rio de Janeiro: Trafficking, Social Networks, and Public Security. Chapel Hill, NC: University of North Carolina Press.

Dewey, Matías. 2011. "Fragile States, Robust Structures: Illegal Police Protection in Buenos Aires". GIGA German Institute of Global and Area Studies, Working Paper Series.

Dewey, Matías. Forthcoming. "Illegal Police Protection. Shielding the Market for Stolen Vehicles in Buenos Aires". Journal of Latin American Studies, Cambridge Univ. Press.

Dewey, Matías and Marcelo Saín. Forthcoming. Clusters of Order.

Eaton, Kent. 2008. "Paradoxes of Police Reform: Federalism, Parties, and Civil Society in Argentina's Public Security Crisis". Latin American Research Review 43: 5-32.

Gambetta, Diego. 1993. The Sicilian Mafia: The Business of Private Protection. Cambridge, Mass.; London: Harvard University Press.

Gayol, Sandra. 1996. "Entre lo deseable y lo posible: perfil de la policía de Buenos Aires en la segunda mitad del siglo XIX". Estudios Sociales 6 (10): 123-138.

Green, Penny and Tony Ward. 2004. State Crime: Governments, Violence and Corruption. London; Sterling, Va.: Pluto Press.

Haller, Mark H. 1990. “Illegal Enterprise: A Theoretical and Historical Interpretation”. Criminology 28: 207-236.

Johnson, Lyman L. 1990. "Changing Arrest Patterns in Three Argentine Cities: Buenos Aires, Santa Fe, and Tucumán, 1900-30". In The Problem of Order in Changing Societies: Essays on Crime and Policing in Argentina and Uruguay, 1750-1940, Lyman Johnson (ed.) Albuquerque, NM: University of New Mexico Press.

Kalmanowiecki, Laura. 2003. "Policing the People, Policing the State: The Police-Military Nexus in Argentina, 1880-1945". In Irregular armed forces and their role in politics and state formation, Davis, Diane E. and Pereira, Anthony W. Cambridge: Cambridge University Press.

Kong Chu, Yiu. 2000. The Triads as Business. London: Routledge.

Kupatadze, Alexander. 2012. Organized Crime, Political Transitions and State Formation in Post-Soviet Eurasia. London: Palgrave Macmillan.

Matthews, Felicity. 2012. "Governance and State Capacity". In The Oxford Handbook of Governance, David Levi-Faur. Oxford: Oxford Univ. Press.

McC. Heyman, Josiah. 1999. States and illegal practices. Oxford; New York: Berg.

Méndez, Juan E and Project Latin America 2000. 1999. The (Un)Rule of Law and the Underprivileged in Latin America. Notre Dame, Ind: Univ. of Notre Dame Press. 
Misse, Michael. 2007. "Mercados ilegais, redes de proteção e organização local do crime no Rio de Janeiro". Estudos Avançados 21 (61): 139-157.

Neuwirth, Robert. 2011. Stealth of Nations: The Global Rise of the Informal Economy. New York: Pantheon Books. Nordstrom, Carolyn. 2000. "Shadows and Sovereigns". Theory, Culture \& Society 17 (January 8): 35-54. Reinhard, Wolfgang. 2007. Geschichte des Modernen Staates. München: Beck.

Reno, William. 1995. Corruption and State Politics in Sierra Leone. Cambridge: Cambridge University Press. Reuter, Peter. 1984. "Police Regulation of Illegal Gambling: Frustrations of Symbolic Enforcement". Annals of the American Academy of Political and Social Science 474: 36-47.

Ruggiero, Vincenzo. 2001. Crime and Markets: Essays in Anti-criminology. London: Oxford University Press. Ruggiero, Vincenzo. 2009. "Transnational Crime and Global Illicit Economies". In Government of the shadows: parapolitics and criminal sovereignty, Eric Wilson (ed.). New York: Pluto Press.

Saín, Marcelo Fabián. 2008. El Leviatán Azul. Buenos Aires: Siglo XXI Ed. Argentina.

Thomson, Janice E. 1994. Mercenaries, Pirates, and Sovereigns: State-Building and Extraterritorial Violence in Early Modern Europe. Princeton: Princeton University Press.

Tilly, Charles. 1985. "War Making and State Making as Organized Crime". In Bringing the State Back In. Cambridge: Cambridge University Press.

Varese, Federico. 2010. "What is Organized Crime?, Introduction to ‘Organized Crime'”. Federico Varese (Ed.), 4 vols. London: Routledge.

Varese, Federico. 2004. The Russian Mafia: Private Protection in a New Market Economy. Oxford: Oxford Univ. Press.

Volkov, Vadim. 2002. Violent Enterpreneurs: The Use of Force in the Making of Russian Capitalism. Ithaca, N.Y.; London: Cornell University Press.

Wilson, Eric. 2009. "Deconstructing the Shadows". In Government of the shadows: parapolitics and criminal sovereignty, Eric Wilson (ed.). New York: Pluto Press.

Zimmermann, Eduardo. 1998. "El Poder Judicial, la construcción del Estado, y el federalismo: Argentina, 1860-1880". In: Anuario IEHS/Instituto de Estudios Histórico-Sociales. Tandil, 8, María E. Argeri and Sandra Chía (Comps.), 275-306. Buenos Aires: Universidad Nacional del Centro.

Dr. Matías Dewey is a researcher at Max Planck Institute for the Study of Societies in Cologne, Germany. He studied sociology and obtained his PhD in Political Science from Rostock University. Currently, his main fields of research are the sociology of illegal markets, police organizations, crime organizations and social theory.

E-mail: dewey@mpifg.de 